\title{
STATUS GIZI SISWA SISWI DI SMA N 8 SURAKARTA
}

\author{
Catur Setyorini $^{1, *}$, Anita Dewi Lieskusumastuti \\ ${ }^{1,2}$ STIKES Mamba'ul 'Ulum Surakarta \\ 1catur.ririn@yahoo.co.id*
}

\begin{abstract}
Abstrak
Latar Belakang : Gizi pada remaja merupakan suatu hal yang harus diperhatikan, banyak dampak yang akan dialami oleh remaja ketika mengalami malnutrisi. Dengan mengkonsumsi makanan yang cukup dan teratur remaja akan tumbuh sehat sehingga akan mencapai prestasi yang gemilang, kebugaran dan sumber daya manusia yang berkualitas.

Tujuan : Penelitian ini bertujuan mengetahui status gizi siswa siswi di SMAN 8 Surakarta.

Metode : Penelitian ini merupakan penelitian deskriptif dengan pendekatan cross sectional. Populasi dalam penelitian ini adalah semua siswa siswi kelas $\mathrm{X}$ di SMAN 8 Surakarta Tahun 2019 sejumlah 369 siswa. Teknik pengambilan sampel yang digunakan adalah Accidental Sampling, sehingga sampel dalam penelitian ini adalah siswa siswi kelas X SMAN 8 Surakarta yang hadir pada saat pelaksanaan skrining kesehatan pada tanggal 4-7 bulan November 2019 sejumlah 340 responden. Alat pengumpulan data menggunakan master tabel. Metode pengumpulan data adalah data primer dan sekunder. Analisa data menggunakan analisa univariat.
\end{abstract}

Hasil : Hasil penelitian didapatkan mayoritas responden berjenis kelamin perempuan sebanyak 207 responden $(60,9 \%)$, mayoritas responden status gizi normal sebanyak 166 responden $(48,4 \%)$, status gizi normal mayoritas pada responden dengan jenis kelamin perempuan sebanyak 119 responden (57,5\%), dan status gizi kurus mayoritas responden dengan jenis kelamin laki-laki sebanyak 51 responden $(38,4 \%)$.

Simpulan : Status gizi siwa siswi di SMAN 8 Surakarta mayoritas normal sebanyak 166 responden $(48,4 \%)$

Kata kunci : Status, Gizi, Siswa siswi

\section{NUTRITIONAL STATUS OF STUDENTS IN SMA N 8 SURAKARTA}

\begin{abstract}
Background: Nutrition in adolescents is something that must be considered, many of the effects that will be experienced by adolescents when experiencing malnutrition. By consuming adequate and regular food, adolescents will grow up healthy so that they will achieve glorious achievements, fitness and quality human resources.
\end{abstract}

Objective: This study aims to determine the nutritional status of students at SMAN 8 Surakarta.

Method: This research is a descriptive study with cross sectional approach. The population in this study were all students of class X in SMAN 8 Surakarta in 2019 
totaling 369 students. The sampling technique used was Accidental Sampling, so that the sample in this study were students of class X SMAN 8 Surakarta who were present at the time of the health screening on 4-7 November 2019 with 340 respondents. Data collection tools use master tables. Data collection methods are primary and secondary data. Data analysis uses univariate analysis.

Results: The results showed the majority of respondents were female respondents as many as 207 respondents (60.9\%), the majority of respondents were normal nutritional status as many as 166 respondents (48.4\%), the majority of normal nutritional status of respondents with female sex were 119 respondents (57, 5\%), and the thin nutritional status of the majority of respondents with male gender as many as 51 respondents ( $38.4 \%)$.

Conclusion: The nutritional status of students of students at SMAN 8 Surakarta the majority are normal as many as 166 respondents (48.4\%)

Keywords: Status; Nutritional; Students

\section{PENDAHULUAN}

Masa remaja merupakan masa yang paling sulit untuk dilalui oleh individu. Masa ini dapat dikatakan sebagai masa yang paling kritis bagi perkembangan pada tahap-tahap kehidupan selanjutnya. Ini dikarenakan pada masa ini terjadi begitu banyak perubahan dalam diri individu baik itu perubahan fisik maupun psikologis. (Proverawati dan Erna, 2011)

Kebutuhan gizi remaja relatif besar, karena mereka masih mengalami pertumbuhan. Selain itu, remaja umumnya melakukan aktivitas fisik lebih tinggi dibanding usia lainnya, sehingga diperlukan zat gizi yang lebih banyak. Pada masa remaja kudapan berkontribusi 30\% atau lebih dari total asupan kalori setiap hari. Remaja harus didorong untuk bertanggung jawab atas pemilihan kudapan yang sehat. Remaja adalah masa peralihan dari anak menuju dewasa, dimana terjadi pertumbuhan fisik, mental dan emosional yang sangat cepat. (Proverawati dan Erna, 2011)

Menurut WHO batasan usia remaja yaitu antara umur 10-19 tahun. Dengan mengkonsumsi makanan yang cukup dan teratur remaja akan tumbuh sehat sehingga akan mencapai prestasi yang gemilang, kebugaran dan sumber daya manusia yang berkualitas. Remaja putri yang terpelihara kadar gizinya akan terpelihara kesehatan reproduksinya, jika kondisi sehat ini terus dipertahankan sampai kondisi memasuki waktu hamil maka akan mendapatkan anak yang sehat dan cerdas. (Proverawati dan Erna, 2011)

Data Riskesdas tahun 2018 menunjukkan bahwa 25,7\% remaja usia 13-15 tahun dan 26,9\% remaja usia 16-18 tahun dengan status gizi pendek dan sangat pendek. Selain itu terdapat $8,7 \%$ remaja usia $13-15$ tahun dan $8,1 \%$ remaja usia 16-18 tahun dengan kondisi kurus dan sangat kurus. Sedangkan prevalensi berat badan lebih dan obesitas sebesar 16,0\% pada remaja usia 13-15 tahun dan 13,5\% pada remaja usia 16-18 tahun. Data tersebut merepresentasikan kondisi gizi pada remaja di Indonesia yang harus diperbaiki.

Berdasarkan baseline survey UNICEF pada tahun 2017, ditemukan adanya perubahan pola makan dan aktivitas fisik pada remaja. Sebagian besar remaja 
menggunakan waktu luang mereka untuk kegiatan tidak aktif, sepertiga remaja makan cemilan buatan pabrik atau makanan olahan, sedangkan sepertiga lainnya rutin mengonsumsi kue basah, roti basah, gorengan, dan kerupuk. Perubahan gaya hidup juga terjadi dengan semakin terhubungnya remaja pada akses internet, sehingga remaja lebih banyak membuat pilihan mandiri. Pilihan yang dibuat seringkali kurang tepat sehingga secara tidak langsung menyebabkan masalah gizi. Perbaikan gizi pada remaja melalui intervensi gizi spesifik seperti pendidikan gizi, fortifikasi dan suplementasi serta penanganan penyakit penyerta perlu dilakukan. Tujuannya untuk meningkatkan status gizi remaja, memutus rantai inter-generasi masalah gizi, masalah penyakit tidak menular dan kemiskinan. (Kemenkes, 2020)

Hasil penelitan menunjukkan sebagian besar siswa di SMA 1 Kampar memiliki status gizi normal sebanyak $73,1 \%$. Dari seluruh sampel menunjukkan bahwa kebiasaan makan harian dalam kategori baik sebanyak $73,1 \%$ dimana nasi menjadi makanan pokok yang paling sering dikonsumsi oleh siswa. Hasil penelitian juga menunjukkan kebiasaan mengonsumsi makan cepat saji dalam kategori sering sebanyak $47,8 \%$ dan tidak ada siswa yang tidak pernah mengonsumsi makanan cepat saji. (Widawati, 2018).

Berdasarkan hasil penelitian Syahfitri, dkk (2017) menunjukkan hasil berdasarkan IMT/U didapatkan status gizi normal (59\%) sebagai nilai tertinggi diikuti status gizi gemuk (23\%), obesitas (10\%), kurus $(7 \%)$ dan sangat kurus $(1 \%)$. Berdasarkan jenis kelamin didapatkan persentase status gizi sangat kurus (2\%) pada jenis kelamin perempuan dan status gizi obesitas paling tinggi pada jenis kelamin laki-laki (15\%). Hasil penelitian yang dilakukan Putra, dkk (2018) dengan judul kebiasaan sarapan terhadap status gizi pada Mahasiswa Universitas Ngudi Waluyo Program Studi Kesehatan Masyarakat secara umum memiliki status gizi normal, dan hanya sedikit yang memiliki status gizi kurus, gemuk dan obesitas. Berdasarkan latar belakang tersebut penulis tertarik untuk meneliti tentang status gizi pada siswa siswi di SMAN 8 Surakarta..

\section{METODE}

Penelitian ini merupakan penelitian deskriptif dengan pendekatan cross sectional. Populasi dalam penelitian ini adalah semua siswa siswi kelas $\mathrm{X}$ di SMAN 8 Surakarta Tahun 2019 sejumlah 369 siswa. Teknik pengambilan sampel yang digunakan adalah Accidental Sampling, sehingga sampel dalam penelitian ini adalah siswa siswi kelas X SMAN 8 Surakarta yang hadir saat pelaksanaan skrining kesehatan pada tanggal 4-7 bulan November 2019 sejumlah 340 responden.

Alat pengumpulan data pada penelitian ini adalah menggunakan master tabel yang berisi nama, umur, jenis kelamin, BB, TB, Status gizi berdasar IMT (Sangat kurus, Kurus, Normal, Gemuk, Obesitas). Metode pengumpulan data yang peneliti gunakan adalah data primer dan sekunder, data primer diperoleh dari hasil pemeriksaan fisik siswa siswi, sedangkan data sekunder adalah data jumlah siswa siswi yang diperoleh dari bidang kesiswaan SMAN 8 Surakarta.

Dalam penelitian ini menggunakan analisa univariat. Analisis univariat untuk mengkategorikan karakteristik responden meliputi jenis kelamin (laki-laki 
dan perempuan) serta status gizi berdasar IMT (Sangat Kurus, Kurus, Normal, Gemuk, Obesitas) yang disajikan dalam bentuk prosentase dengan menggunakan distribusi frekuensi.

\section{HASIL DAN PEMBAHASAN}

Tabel 1. Distribusi frekuensi karakteristik responden berdasarkan jenis kelamin

\begin{tabular}{clcc}
\hline No & \multicolumn{1}{c}{ Jenis Kelamin } & frekuensi & Prosentase $(\%)$ \\
\hline 1 & Laki-laki & 133 & 39,1 \\
2 & Perempuan & 207 & 60,9 \\
& Jumlah & 340 & 100 \\
\hline
\end{tabular}

Berdasarkan tabel 1 menunjukkan mayoritas responden perempuan sebanyak 207 responden $(60,9 \%)$.

Tabel 2 Distribusi frekuensi status gizi responden berdasarkan IMT

\begin{tabular}{|c|c|c|c|}
\hline No & Pendidikan & frekuensi & Prosentase $(\%)$ \\
\hline 1 & Sangat Kurus & 16 & 4,7 \\
\hline 2 & Kurus & 88 & 25,9 \\
\hline 3 & Normal & 166 & 48,8 \\
\hline 4 & Gemuk & 50 & 14,7 \\
\hline \multirow[t]{2}{*}{5} & Obesitas & 20 & 5,9 \\
\hline & Jumlah & 340 & 100 \\
\hline
\end{tabular}

Berdasarkan tabel 2 menunjukkan mayoritas responden dengan status gizi normal sebanyak 166 responden $(48,8 \%)$.

Tabel 3. Distribusi status gizi responden berdasar jenis kelamin

\begin{tabular}{lcccc}
\hline \multirow{1}{*}{ Status Gizi } & \multicolumn{4}{c}{ Jenis Kelamin } \\
\cline { 2 - 5 } & F & \% & F & Laki-laki \\
\cline { 2 - 5 } & 5 & 2,4 & 11 & 8,3 \\
\hline Sangat kurus & 37 & 17,9 & 51 & 38,4 \\
Kurus & 119 & 57,5 & 47 & 35,3 \\
Normal & 38 & 18,4 & 12 & 9 \\
Gemuk & 8 & 3,8 & 12 & 9 \\
Obesitas & 207 & 100 & 133 & 100 \\
Total & & &
\end{tabular}

Berdasarkan tabel diatas, terlihat status gizi normal mayoritas berjenis kelamin perempuan sebanyak 119 responden $(57,5 \%)$, dan status gizi kurus mayoritas dengan jenis kelamin laki-laki sebanyak 51 responden $(38,4 \%)$.

Status gizi merupakan keadaan tubuh yang dipengaruhi oleh zat-zat gizi tertentu sebagai akibat dari konsumsi makanan. Tiga faktor yang berperan besar mempengaruhi keadaan gizi kurang yaitu, anak tidak cukup mendapat asupan gizi yang seimbang dan memadai, pola asuh orang tua yang tidak mengetahui tentang pemberian asupan makanan cukup gizi dan anak yang sedang menderita penyakit infeksi. (Adnyani, 2012) 
Status gizi dapat diketahui dengan menghitung Indeks Massa Tubuh (IMT). Indeks Massa Tubuh dihitung dengan cara membagi bobot badan $(\mathrm{kg})$ dengan kudrat tinggi badan $(\mathrm{m}): \mathrm{IMT}=\mathrm{BB} / \mathrm{TB}^{2}$, BB adalah bobot badan $(\mathrm{kg})$ dan TB adalah tinggi badan $(\mathrm{m})$. Banyak dampak yang akan dialami oleh remaja ketika mengalami malnutrisi, seperti pada remaja yang kurang gizi atau terlalu kurus akan mempengaruhi reproduksi. Sedangkan pada remaja yang mengalami gizi lebih atau gemuk akan berisiko terjadinya penyakit degeneratif semakin tinggi, seperti hipertensi, diabetes melitus, penyakit jantung koroner dan lain-lain. (Supariasa, 2014)

Berdasarkan hasil penelitian dapat diketahui dari tabel 1 bahwa kategori siswa terbanyak adalah siswa dengan jenis kelamin perempuan yaitu sebanyak 207 orang $(60,9 \%)$. Hasil penelitian ini sejalan dengan penelitian yang dilakukan Syahfitri, dkk (2016) di SMP Negeri 13 Pekanbaru bahwa responden paling banyak dengan jenis kelamin perempuan sebanyak 190 orang $(66 \%)$.

Data Riskesdas tahun 2018 menunjukkan bahwa 8,7\% remaja usia 13-15 tahun dan 8,1\% remaja usia 16-18 tahun dengan kondisi kurus dan sangat kurus. Sedangkan prevalensi berat badan lebih dan obesitas sebesar $16,0 \%$ pada remaja usia 13-15 tahun dan 13,5\% pada remaja usia 16-18 tahun.

Hasil penelitian pada tabel 2 didapatkan bahwa status gizi siswa-siswi SMAN 8 Surakarta dengan pengukuran IMT diperoleh gizi sangat kurus sebanyak 16 orang $(4,7 \%)$, gizi kurus sebanyak 88 orang $(25,9 \%)$, gizi normal sebanyak 166 orang $(48,8 \%)$, gizi gemuk sebanyak 50 orang $(14,7 \%)$ dan status gizi obesitas sebanyak 20 (5,9\%). Sama halnya penelitian yang dilakukan Widawati (2018) bahwa sebagian besar siswa SMAN 1 Kampar Kabupaten Kampar memiliki status gizi yang normal $(73,1 \%)$. Status gizi yang normal dapat terjadi apabila tubuh cukup memperoleh zat-zat gizi yang digunakan secara efisien, sehingga memungkinkan pertumbuhan fisik, perkembangan otak, kemampuan kerja mencapai tingkat optimal. (Indra dan Wulandari, 2013)

Status gizi gemuk dan obesitas pada penelitian ini masih ditemukan sebesar 14,7 \% dan 5,9\%. Kegemukan atau obesitas adalah suatu kondisi berupa kelebihan lemak tubuh yang terakumulasi sedemikian rupa sehingga menimbulkan dampak merugikan bagi kesehatan, yang kemudian menurunkan harapan hidup dan meningkatkan masalah kesehatan. Seseorang dianggap menderita kegemukan bila Indeks Massa Tubuh (IMT) lebih dari $30 \mathrm{~kg} / \mathrm{m}^{2}$. Kegemukan meningkatkan peluang terjadinya berbagai macam penyakit, khususnya penyakit jantung, diabetes, dan penyakit lainnya. Kegemukan sangat sering disebabkan oleh kombinasi antara asupan energi makanan yang berlebihan, kurangnya aktivitas fisik, dan kerentanan genetik. (Almatsier dalam Syahfitri, 2016).

Hal ini terjadi salah satunya disebabkan karena faktor remaja yang sangat suka mengkonsumsi makanan siap saji dan didukung dengan ketersediaan makanan yang murah, cepat tetapi tidak sehat seperti Junk Food. Berdasarkan tanya jawab singkat yang peneliti lakukan, siswa-siswi SMAN 8 Surakarta jarang melakukan sarapan dirumah dan lebih menyukai makan diluar rumah bersama teman-teman, sehingga waktu makan tidak teratur, akibatnya mengganggu sistem pencernaan (gangguan maag atau nyeri lambung). 
Pada penelitian ini status gizi sangat kurus dan kurus persentase berjumlah $4,7 \%$ dan $25,9 \%$. Tubuh seseorang kurus umumnya disebabkan oleh ketidak seimbangan antara energi yang masuk dan keluar dari tubuh, energi yang keluar lebih besar dari energi yang masuk. Hal ini dapat disebabkan antara lain oleh kurang makan, menu makan yang tidak seimbang nafsu makan menurun atau aktivitas fisik yang terlalu berat. Penyebab lain yang sering ialah penyakit dengan panas badan tinggi, penyakit kronis seperti TBC, diabetes, kanker, penyakit saluran pencernaan atau penyakit lain yang menyebabkan turunnya nafsu makan. Pada penyakit infeksi umumnya terjadi peningkatan metabolisme tubuh dan pemecahan jaringan yang memerlukan energi ekstra, selain itu orang yang kurus ada kemungkinan karena konstitusi atau pembawaannya. Bobot badan orang seperti ini biasanya kurang karena rangka dan otot-otot kecil. ( Almatsier dalam Syahfitri, 2016). Untuk menghindari terjadinya gizi kurang, makanan yang dikonsumsi remaja harus bervariasi seimbang antara kandungan protein, lemak, vitamin dan mineralnya.

Pada tabel 3 dari 340 sampel siswa didapatkan persentase status gizi sangat kurus paling tinggi pada jenis kelamin laki-laki sebanyak 11 orang $(8,3 \%)$ dan status gizi kurus paling tinggi pada jenis kelamin laki-laki sebanyak 51 orang $(38,4 \%)$. Hal ini disebabkan karena pada aktifitas fisik anak laki-laki dan perempuan berbeda, anak laki-laki memiliki aktifitas yang lebih aktif dibandingkan pada anak perempuan. Dimana energi yang dikeluarkan oleh anak laki-laki lebih banyak dibandingkan dengan anak perempuan yang tidak terlalu aktif bermain disekolah.

Status gizi normal paling tinggi pada jenis kelamin perempuan sebanyak 119 orang $(57,5 \%)$. Remaja perempuan cenderung lebih memperhatikan bentuk tubuhnya dibandingkan dengan laki-laki sehingga perempuan cenderung memiliki status gizi normal. Remaja putri sering menghindari beberapa jenis bahan makanan seperti telur dan susu. Susu dianggap minuman untuk anak-anak atau dihubungkan dengan kegemukan. (Proverawati dan Erna, 2011)

Status gizi gemuk paling tinggi pada jenis kelamin perempuan sebanyak 38 orang $(18,4 \%)$, hal ini dikarenakan aktivitas fisik siswi perempuan tidak sebanyak siswa laki-laki, dapat terlihat saat jam istirahat siswa perempuan lebih banyak berada didalam kelas dan hanya bermain disekitar lapangan.

Sementara status gizi obesitas paling tinggi pada jenis kelamin laki-laki sebanyak 12 orang (\%). Hal ini sejalan dengan hasil analisis Ratna dalam Syahfitri (2016) dengan judul hubungan antara jenis kelamin dengan status gizi remaja diperoleh bahwa ada sebesar $9,7 \%$ remaja berjenis kelamin laki-laki memiliki status gizi lebih sedangkan perempuan yang memiliki status gizi lebih ada $8,7 \%$. Artinya remaja laki-laki mempunyai peluang 1,119 kali terjadi gizi lebih dibanding remaja perempuan. Sejalan dengan penelitian yang telah dilakukan oleh Ruslie dan Darmadi (2012) dengan judul analisis regresi logistik untuk faktor-faktor yang mempengaruhi status gizi remaja, bahwa mahasiswa laki-laki berisiko obesitas 1,890 kali dibandingkan mahasiswa perempuan serta faktor-faktor yang mempengaruhi status gizi remaja antara lain asupan makan, aktivitas fisik, body image, dan gender. 
Mempertahankan berat badan ideal sangat penting karena menentukan tercapainya status kesehatan yang optimal. Pemantauan berat badan secara berkala merupakan tindakan preventif terhadap obesitas maupun KEK. Namun dalam hal pengontrolan berat badan diperlukan cara yang benar sehingga tetap memenuhi syarat pola konsumsi yang benar dan sehat, dan ditunjang pola aktivitas fisik yang tepat sehingga tercapai status gizi yang ideal. Pengaruh lingkungan cukup kuat bagi remaja dan sangat menentukan perilaku remaja. Secara psikologis remaja berusaha untuk sesuai dengan nilai-nilai yang dianut oleh kelompok sebayanya. Penentuan diri remaja dalam berperilaku banyak dipengaruhi oleh tekanan dari kelompok teman sebaya, karena teman sebaya merupakan sumber referensi utama dalam hal persepsi dan sikap yang berkaitan dengan gaya hidup mereka termasuk pola aktivitas dan pola makan yang berdampak pada status gizinya. (Ryde dalam Zuhdy dkk, 2015)

\section{SIMPULAN}

Hasil penelitian didapatkan mayoritas responden berjenis kelamin perempuan sebanyak 207 responden $(60,9 \%)$, mayoritas responden status gizi normal sebanyak 166 responden $(48,4 \%)$, status gizi normal mayoritas pada responden dengan jenis kelamin perempuan sebanyak 119 responden (57,5\%), dan status gizi kurus mayoritas responden dengan jenis kelamin laki-laki sebanyak 51 responden $(38,4 \%)$.

\section{SARAN}

Diharapkan dilakukan penelitian lebih lanjut mengenai hubungan status gizi dengan aktifitas fisik pada remaja. Kepada orang tua agar lebih memperhatikan status gizi anak dengan memperhatikan keseimbangan asupan zat gizi pada anak dan memperbaiki kualitas makan anak karena masa remaja merupakan masa pertumbuhan yang rentan mengalami masalah gizi. Kepada sekolah diharapkan untuk memberi penyampaian materi mengenai gizi seimbang dan bekerja sama dengan instansi kesehatan terkait dengan mengelompokkan sesuai hasil status gizi responden.

\section{DAFTAR PUSTAKA}

Adnyani NKW. 2012. Hubungan Status Gizi Dengan Siklus Menstruasi Pada Remaja Putri Kelas X di SMA PGRI 4 Denpasar. Tesis.Program Studi Ilmu Keperawatan Fak. Kedokteran Universitas Udayana.

Indra D dan Wulandari Y. 2013. Prinsip-prinsip Dasar Ahli Gizi. Jakarta: Dunia Cerdas.

Kemenkes. Gizi saat remaja tentukan kualitas keturunan. Jakarta. 2020 https://www.kemkes.go.id/article/view/20012600004/gizi-saat-remajatentukan-kualitas-keturunan.html. Diakses pada tanggal 8 Maret 2020 Jam 10.00 WIB

Proverawati dan Erna, 2011. Ilmu Gizi untuk Keperawatan dan Gizi Kesehatan. Yogyakarta : Nuha Medika 
Putra, A., Syafira, D. N., Maulyda, S., Afandi, A., \& Wahyuni, S. (2018). Kebiasaan Sarapan pada Mahasiswa Aktif. HIGEIA (Journal of Public Health Research and Development), 2(4), 577-586.

Kementerian Kesehatan Badan Penelitian dan Pengembangan Kesehatan. Hasil Utama Riskesdas tahun 2018. https://www.kemkes.go.id/resources/download/info-terkini/hasil-riskesdas2018.pdf

Ruslie, R. H., \& Darmadi, D. 2012. Analisis Regresi Logistik Untuk FaktorFaktor Yang Mempengaruhi Status Gizi Remaja. Majalah Kedokteran Andalas, 36(1), 62-72.

Supariasa ID, Bakri B, Fajar I. Penilaian Status Gizi. Cetakan 2014. Jakarta: EGC.

Syahfitri, Y., Ernalia, Y., \& Restuastuti, T. 2017. Gambaran status gizi siswasiswi SMP negeri 13 pekanbaru tahun 2016 (Doctoral dissertation, Riau University).

Widawati, W. 2018. Gambaran Kebiasaan Makan Dan Status Gizi Remaja Di SMAN 1 Kampar Tahun 2017. Jurnal Gizi: Nutritions Journal, 2(2).

Zuhdy, N., Ani, L. S., \& Utami, N. A. 2015. Physical Activity, Food Consumption and Nutritional Status among Female High School Students in North Denpasar. Public Health and Preventive Medicine Archive, 3(1). 